\begin{tabular}{|c|c|}
\hline \multirow{3}{*}{ 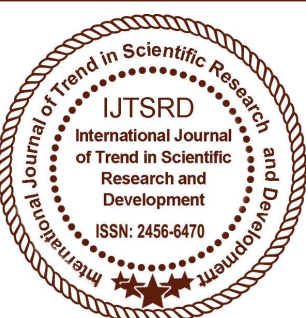 } & $\begin{array}{l}\text { International Journal of Trend in Scientific } \\
\text { Research and Development (IJTSRD) }\end{array}$ \\
\hline & International Open Access Journal \\
\hline & ISSN No: 2456 - 6470 | www.ijtsrd.com | Volume - 2 | Issue - 5 \\
\hline
\end{tabular}

\title{
Problems and Challenges of Edible Oil Mill Workers: A Sociological Study in Challakere Talukin Chitradurga District
}

\author{
Thippeswamy. $\mathbf{R}^{1}$, Dr. Chandrashekar. $\mathbf{E}^{2}$ \\ ${ }^{1}$ Research Scholar, ${ }^{2}$ Associate Professor \\ Department of PG Studies and Research in Sociology, Kuvempu University, Jnana Sahyadri, \\ Shankaraghatta, Shivamogga, Karnataka, India
}

\section{ABSTRACT}

India is developing country in the world. Since Independence the government of India has undertaken several measures for industrial development. Industries are the back bone of every nation, India is not exception these, the contribution of industries in GDP was found increasing trend, which are the most important and significant economic determinant. After industrial revolution, industries took larger part in economic activities. Most of the industrial labour working in unorganized sector without job security and living in very poor condition. They are suffering from basic amenities such are health, education and livelihood. Even though the contribution of the Oil Mill workers in the development of nation economy is more, yet they are facing several problems. The present paper discusses the Problems and challenges of oil mill's workers: A sociological study. This study was based on both primary and secondary sources of data. Primary data gathered through primary investigation from the workers of different edible oil mills in Challakere taluk of Chithradurga District by using the interview schedule method. The secondary data collected from various sources such as annual reports, published articles and documents with the organizations, data from District Industrial Centre (DIC) Chitradurga District, magazines, journals, newspapers, internet, reports, records, etc. The objectives of the study are to study the working conditions of the oil mill's workers and to study the health problems of the oil mill's workers, and to analyze the income and expenditure pattern of oil mill's workers, to identify the living conditions of oil mill's workers in Challakere Taluk of Chitradurga District.
Keywords: GDP, Oil Mill Workers, Health, Education and Livelihood

\section{INTRODUCTION}

India is one of the emerging countries in the world. Since independence industrial development in India rapidly growing and the contribution of industrial development in GDP was found increasing trend. Industries are the back bone of every nation, which are the most important and significant economic determinant. After industrial revolution, industries took larger part in economic activities. In India 92 per cent of labour working in informal sector and only 10 per cent of the labour working informal sector. This is evidence that, majority of the labour working in informal sector. The contribution of unorganized sector in employment during the period 1977-78 was about 92.2 which were in the year 1993-94 about 92.7. Hence initial $90^{\text {th }}$ decade before liberalization and privatization it has big informal sector in the country. Every nation would like to establish many industries for economic development. Earlier the situation was significantly good in this regard, previous studies has also reveal the same opinion. Might be the first half of $19^{\text {th }}$ century was not so flourished concerning to the industry workers or the labourers of the industry. These labours are working in an unorganized sector without job security, and living in vulnerable situation and struggling for their livelihood having less educational and economic background living in filthy circumstances. Keeping all this in mind the present study would like to concentrate on the problems and challenges of oil mil labourers in challakere taluk of Chitradurga district is the need for the study. 


\section{NEED OF THE STUDY:}

In India majority of the labour working in unorganized sectors and more contribution in the national GDP but they are facing several sorts of problems. People who are engaged in oil mill work are facing serious problems such are poverty, health problems, family problems, poor housing facilities, insufficient nutritious food, low daily wages, long working hours, problem of basic facilities, unhygienic of the environment, illiteracy, physically, mentally stress and mill owners and labours relationship debts etc. The researcher is keen to learn about the conditions of oil mill workers. Hence the present study is considered highly justifiable.

\section{REVIEW OF LITERATURE:}

S A Ferdous and Er, Ah Choy and Begum, Halima, (2015), in their research paper entitled "Malaysian Oil Palm Industry: Prospect and Problem", analyzed the oil palm in Malaysia has seen major progress. Oil palm production has brought about unlimited economic profits and currently it is an emerging economic sector in Malaysia. At present, Malaysia financial records for a vast contribution to world's palm oil production and export which is 39 per cent and 44 per cent respectively. A huge 17.73 million tons of palm oil and 2.13 tons of palm kernel oil have been produced from about 4.49 million hectares of land. Malaysia has a vital role to play in achieving the rising global need for oils and fats, as Malaysia is a major manufacturer and exporter countries of palm oil and palm oil products. The authors highlighted made an attempt to discuss with the current scenario of oil palm cultivation prospects and practices for income generation. Describing more than a few issues and consequences that have impact to the oil palm production is also within the purview of this study area.

Hallur S. C. unpublished M.Phil. Thesis entitled on "The Problems and Prospects of Edible Oil Industry in Bijapur" submitted to Karnataka University, Bijapur in 1992, this research work highlighted the socio-economic reasons are rapid developed the edible oil industry in Bijapur. The study found that the present situation of the edible oil industry through the 32 sample oil mills. In the here situation this industry is facing number of problems were mentioned and the suggestions were made for the further sound development of this industry. The study found that were related to the purchase of oilseeds, sale of oilseeds,finance, process and production, employment of skilled labour, location and the government policies. Finally author suggestions were made to develop production and marketing system of edible oil business for strengthening this business in Bijapur also discussed in this thesis.

\section{OBJECTIVE OF THE STUDY:}

i. To know the working conditions of the oil mill's workers in Challakere taluka of Chitradurga district.

ii. To assess the health problems of the oil mill's workers in Chllakere taluka of Chitradurga district.

iii. To analyze the income and expenditure pattern of oil mill's workers in the study area.

iv. To identify the job satisfaction of the oil mill's workers in Challakere taluka of Chtradurga district.

\section{METHODOLOGY:}

The present study was based on both primary and secondary sources of data. The primary data were gathered through primary investigation from the workers of different Edible oil mills in Challakere Taluk of Chithradurga District by using the interview schedule method.A total of 150 respondents who are working in oil mills have been chosen for the study.The secondary data collected from various sources such as annual reports, published Journal articles and relevant documents with the organizations, District Industrial Centre (DIC) report Chitradurga District.

\section{RESULT AND DISCUSSION}

The study based on primary investigation, analysis of primary data which have been gathered through field survey. Total of 150 respondents have been interviewed for the purpose of the study. These results are interpreted in below.

\section{Details of working of the Respondents:}

The detailed working of the respondents in the study area is presented in the below Table 1.

\section{Table .01}

Details of monthly working of the Respondents:

\begin{tabular}{|l|l|l|l|}
\hline Sl. No & \multicolumn{1}{|c|}{ No. of months } & $\begin{array}{c}\text { Respo- } \\
\text { ndents }\end{array}$ & $\begin{array}{c}\text { Perce- } \\
\text { ntage }\end{array}$ \\
\hline 1 & Less than 6 months & 89 & 59.33 \\
\hline 2 & 6 to 9 months & 47 & 31.33 \\
\hline 3 & 10 to 11 months & 14 & 9.33 \\
\hline & Total & $\mathbf{1 5 0}$ & $\mathbf{1 0 0 . 0 0}$ \\
\hline
\end{tabular}

Source: Data gathered through field survey 2017 
It can be observed from the above Table 01 show that, details of monthly working of the respondents in oil mills. Of the total 150 respondents were interviewed 59.33 per cent of the respondents were opinion that they are working less than 6 month and 31.33 percent of the respondents opinion that 6 to 9 month, remaining 9.33 per cent of the respondents said 10 to 11 month working in oil mills.

\section{Details of working Hours of the Respondents:}

Working hour is the essential need to enhance the satisfaction of the workers, minimum working hour and wages increases the willing to work of the workers. The detailed working hours of the respondents in Callakere taluck of Chitradurga District is presented in the below Table 2

\section{Table.02}

Details of working Hours of the Respondents:

\begin{tabular}{|l|l|l|l|}
\hline $\begin{array}{l}\text { SI. } \\
\text { No }\end{array}$ & $\begin{array}{c}\text { No. of Working } \\
\text { Hours }\end{array}$ & Respondents & Percentage \\
\hline 1 & Less than 8 hours & 19 & 12.66 \\
\hline 2 & 8 to 9 hours & 68 & 45.33 \\
\hline 3 & 9 to 10 & 37 & 24.66 \\
\hline 4 & 10 to 11 & 18 & 12.00 \\
\hline 5 & More than 11 & 08 & 5.33 \\
\hline & Total & $\mathbf{1 5 0}$ & $\mathbf{1 0 0 . 0 0}$ \\
\hline
\end{tabular}

Source: Data gathered through field survey 2017

It has been observed from the above Table-02 show that, details of working hour of the oil mill workers in the study area. A total of 150 respondents were interviewed of which 12.66 per cent of the respondents opinion belongs to they are working less than 8 hours per day, 45.33 per cent of the respondents said that 8 to 9 hours per day and 24.66 per cent of them opined that 9 to 10 hour, 12 per cent of the workers said they are working 10 to 11 hour per day and the remaining 5.33 per cent respondents opinion belongs to more than 11 hours working per day in oil mill.

\section{Health related issues of the Respondents:}

Health is one of the indicators of development of any country. Good health facility enhance more working hours as a result more output is possible on the other hand poor heath results less output in the industry. The details of health problems of the oil industry workers in Challakere taluck of Chitradurga District is presented in below Table.
Table.03

Health related issues of the Respondents:

\begin{tabular}{|l|l|l|l|}
\hline $\begin{array}{l}\text { SI. } \\
\text { No }\end{array}$ & Type of IIlness & $\begin{array}{l}\text { Respondents } \\
(\mathbf{N}=\mathbf{1 5 0})\end{array}$ & Percentage \\
\hline 1 & Chest pain & 87 & 58.00 \\
\hline 2 & $\begin{array}{l}\text { Coughcold- } \\
\text { fever }\end{array}$ & 42 & 28.00 \\
\hline 3 & Typhoid & 06 & 4.00 \\
\hline 4 & Eye ailments & 23 & 15.33 \\
\hline 5 & Asthama & 19 & 12.66 \\
\hline 6 & Back ache & 33 & 22.00 \\
\hline 7 & Muscle pain & 23 & 15.33 \\
\hline 8 & Acetic & 42 & 28.00 \\
\hline 9 & Leg pain & 25 & 16.66 \\
\hline 10 & Others & 13 & 8.66 \\
\hline
\end{tabular}

Source: Data gathered through field survey 2017

It can be data presented in the above Table 03 , show that health related issues of respondents, A total of 150 respondents personally interviewed, 58.00 per cent respondents opinion belongs to Chest pain, 28.00 per cent respondents opinion belongs to Cough-coldfever, 04.00 per cent respondents opinion belongs to Typhoid, 15.33 per cent respondents opinion belongs to Eye ailments, 12.66 per cent respondents opinion belongs to Asthama, 22.00 per cent respondents opinion belongs to Back ache, 15.33 per cent respondents opinion belongs to Muscle pain, 28.00 per cent respondents opinion belongs to acetic, 16.66 per cent respondents opinion belongs to Leg pain and 08.66 per cent respondents opinion belongs to others. Hence majority of the respondents belongs to opinion Chest pain in the health status.

\section{Treatment taken Hospital:}

The details of treatment taken by the respondents in the study area is provided in below Table

Table-04 Treatment taken hospital of the Respondents

\begin{tabular}{|c|l|l|l|}
\hline $\begin{array}{c}\text { SI. } \\
\text { No }\end{array}$ & $\begin{array}{c}\text { Type of } \\
\text { Hospital }\end{array}$ & Respondents & Percentage \\
\hline 1 & Government & 109 & 72.66 \\
\hline 2 & Private & 12 & 8.00 \\
\hline 3 & Both & 29 & 19.33 \\
\hline & Total & $\mathbf{1 5 0}$ & $\mathbf{1 0 0 . 0 0}$ \\
\hline
\end{tabular}

Source: Data gathered through field survey 2017

It can be seen from the above table-04 show that, details of treatment taken by the oil mill workers in the study area. Of the total 150 respondents were interviewed 72.66 per cent of the respondents replied 
they were taken treat from Government hospitals, 8 per cent of the respondents said they are taken treat from private hospitals and the remaining 19.33 per cent of the respondents opined that they were taken treatment for health dieses in both Government and private hospitals.

Annual health expenditures of the Respondents: The annual expenditure of the respondents is presented in below table

Table.05

Annual health expenditures of the Respondents

\begin{tabular}{|l|l|l|l|}
\hline $\begin{array}{l}\text { Sl. } \\
\text { No }\end{array}$ & \multicolumn{1}{|c|}{ Amount } & Respondents & Percentage \\
\hline 1 & Less than 5000 & 23 & 15.30 \\
\hline 2 & $5001-10.000$ & 79 & 52.70 \\
\hline 3 & More than 10.000 & 48 & 32.00 \\
\hline & Total & $\mathbf{1 5 0}$ & $\mathbf{1 0 0 . 0 0}$ \\
\hline
\end{tabular}

Source: Data gathered through field survey 2017

The data presented in the above Table- 05 show that, details of annual expenditure of the respondents. A total of 150 respondents were interviewed of which 15.30 per cent of the respondents replied that their annual expenditure was less than Rs.5000 and 52.70 per cent of them said that their annual expenditure was Rs5001 to 10,000 and the remaining 32.00 per cent of them replied their annual expenditure was more than Rs10000 in the study area.

\section{Job satisfaction of the Respondents;}

Job satisfaction is essential to willing to work of the Industrial worker. If the satisfaction of the work worker more desire to work in the oil industry. The detailed job satisfaction of the oil mill workers is provided in the below table.

\section{Table.06}

Job satisfaction of the Respondents

\begin{tabular}{|l|l|l|l|}
\hline $\begin{array}{c}\text { Sl. } \\
\text { No }\end{array}$ & \multicolumn{1}{|c|}{$\begin{array}{c}\text { Job } \\
\text { Statisfaction }\end{array}$} & Respondents & Percentage \\
\hline 1 & Statisfaction & 16 & 10.70 \\
\hline 2 & Dis satisfaction & 134 & 89.30 \\
\hline & Total & $\mathbf{1 5 0}$ & $\mathbf{1 0 0 . 0 0}$ \\
\hline
\end{tabular}

Source: Data gathered through field survey 2017

It is reveals from the primary survey, details of job satisfaction of the respondents. Of the total 150 respondents were interviewed 10.70 per cent of the respondents are replied they are satisfied in the work and 89.30 per cent of them opined that they are not satisfaction in the job.

\section{Reasons for job un-satisfaction}

The details of reason for job un-satisfaction is presented in the below table.

Table.07

Reasons for job un-satisfaction of the Respondents

\begin{tabular}{|l|l|l|l|}
\hline $\begin{array}{l}\text { SI. } \\
\text { No }\end{array}$ & Reasons & $\begin{array}{l}\text { Respondents } \\
(\mathbf{N = 1 5 0 )}\end{array}$ & Percentage \\
\hline 1 & $\begin{array}{l}\text { Low wages at } \\
\text { the origin }\end{array}$ & 136 & 90.66 \\
\hline 2 & $\begin{array}{l}\text { Long hours of } \\
\text { work }\end{array}$ & 117 & 78.00 \\
\hline 3 & No job security & 150 & 100.00 \\
\hline 4 & No basic facility & 128 & 85.33 \\
\hline 5 & $\begin{array}{l}\text { No medical } \\
\text { facility }\end{array}$ & 141 & 94.00 \\
\hline
\end{tabular}

Source: Data gathered through field survey 2017

It can be data presented above the Table 07 details of Reasons for job un-satisfaction of the respondents. A total of 150 respondents were personally interviewed, 90.66 per cent respondents opinion belongs to Low wages at the origin, 78.00 per cent respondents opinion belongs to Long hours of work, out of 100 per cent respondents opinion belongs to No job security, 85.33 per cent respondents opinion belongs to No basic facility, 94.00 per cent respondents opinion belongs to no medical facility. Hence majority of the respondent's opinion to there is no job security in the Oil mils.

\section{MAJOR FINDINGS:}

Based on the analysis of primary data some of the important major findings of the study have been presented as follows:

$>$ It is found from the primary survey 59.33 per cent of the respondents were working less than 6 month in oil mill Industry in Challakere taluck of Chitradurga District.

$>$ A majority 45.33 per cent of the respondents are working 8 to 9 hours per day in the study area.

In the study area 72.66 per cent of the respondents were taken treat for ill health in Government hospitals rather than private hospital.

Majority of the respondents their annual expenditure was Rs5001 to 10,000

Most of the oil mill workers are not satisfaction in the job due to more work and less wage and poor working condition. 


\section{SUGGESTION:}

Based on the above findings some of the useful findings have been made such are:

There is need to 12 month work to the workers those who are working in oil mill industries for their fulfillment of basic requirements.

$>$ Government should fixed minimum working hours of the oil mills workers it should be less than 8 hours in challakere taluck of Chitradurga district.

$>$ Government should provide free health facility for oil mills workers in private hospital for their better treatment in private hospitals in the study area.

$>$ There need to enhance the annual income of the respondents in oil mill workers.

Government should provide job satisfaction of the oil mill industry workers by providing various incentives in the field of work satisfaction.

\section{CONCLUSION:}

Even though efforts made by both the Central and State governments for the betterment of Industrial workers, even today they are facing several sorts of problems, like low wage rate, no proper protection, job insecurity, lack of financial facilities in India. The present discussion is concern the oil mil industrial

workers in Challakere taluck of Chitradurga district are facing ilhealth, job insecurity, financial problems, low wage, lack of government facility. Hence there is urgent need to proper policies, programmes and job security and health insurance scheme for betterment of oil mill workers in the near future.

\section{REFERENCES:}

1. K. G. Parashuram (2011) Contract Labour in India Problems and Prospects, Prateeksha Publication, jaipur

2. Gajalakshmi (1998,) Problems and perspectives of women labour in India, Mohit publications, New Delhi.

3. Ramanujam G. R., (1986), Indian Labour Movement, Sterling publishers private Limited. Delhi.

4. lam, A S A Ferdous and Er, Ah Choy and Begum, Halima, (2015), Malaysian Oil Palm Industry: Prospect and Proble, Journal of Food, Agriculture and Environment, volume 1313,pages-143-148

5. Hallur S. C. unpublished M. Phil. thesis on "The Problems and Prospects of Edible Oil Industry in Bijapur" submitted to Karnataka University, Bijapur in 1992. 